\title{
Hábitat e estatuto da Cidade
}

\author{
Paulo César Xavier Pereira
}

Hábitat, referindo-se à noção de arquitetura e especificando práticas urbanas novas, denomina uma nova área de concentração na pós-graduação proposta por docentes da FAUUSP. A sua proposição visa estimular o conhecimento crítico da produção da cidade e valorizar as experimentações inovadoras em políticas públicas, que signifiquem a superação de conflitos e a melhoria da qualidade de vida para o conjunto da população.

Assim, com esta preocupação foi organizado por integrantes do Laboratório de Habitação e Assentamentos Humanos - LabHab e do Laboratório de Fundamentos da Arquitetura e Urbanismo - LabFAU um seminário sobre o Estatuto da Cidade, no dia 28 de agosto de 2001, visando discutir a Lei Federal n. 10.257/2001, sancionada em julho.

Para este seminário, que contou com cerca de 400 participantes, foram especialmente convidados representantes da promotoria pública, da Associação de Juízes pela Democracia e funcionários da administração pública, tendo a participação do secretário municipal da Habitação de São Paulo e de professores da FAUUSP, aos quais foram propostas indagações sobre o caráter inovador do estatuto e de quais seriam as possibilidades que se abriam para as práticas urbanas populares com a nova lei.

O estatuto, ao regulamentar os artigos 182 e 183 da Constituição Federal inova quando introduz legalmente o princípio de que a propriedade urbana está sujeita ao cumprimento de sua função social. Foi na Constituição de 1988 que, pela primeira vez, contemplou-se o tema urbano em um texto constitucional. Nesse sentido, o estatuto, ao responder à necessidade de sua regulamentação é inovador, sobretudo porque no parágrafo único do capítulo I - Diretrizes Gerais, em seu artigo $1^{\circ}$ afirma que: "Para todos os efeitos, esta Lei, denominada Estatuto da Cidade, estabelece normas de ordem pública e interesse social que regulam o uso da propriedade urbana em prol do bem coletivo, da segurança $e$ do bem-estar dos cidadãos, bem como do equilíbrio ambiental."

Assim, o Estatuto da Cidade veio aumentar a importância nacional da temática urbana e reforçar a busca de soluções democráticas para o problema habitacional. Sendo conhecido que a maioria da população brasileira vive hoje em um hábitat urbano, o compromisso da universidade pública com a sociedade na busca destas soluções renova a necessidade de aprofundar o conhecimento crítico da urbanização contemporânea e a preparação contínua de um novo tipo de pesquisador, inovador e profissional da cidade. 
As apresentações e o debate confirmaram a necessidade e a oportunidade de constituir um campo de reflexão sobre a produção e a apropriação do hábitat urbano, tendo como eixo central de pesquisa e ensino os conflitos sociais e os problemas urbanos gerados pela utilização predatória da cidade contemporânea. Focou-se, particularmente, o caso de São Paulo, mas pode se verificar como os problemas e a história da construção desta cidade encontra semelhança em outras tantas cidades brasileiras. E mais importante, as manifestações do público presente e o tipo de questões suscitadas apontaram para a necessidade de formar profissionais inovadores capazes de conduzir de maneira nova e democrática o processo de urbanização e de construção das cidades.

Mostrou-se que, historicamente, a forma de produção e uso das cidades brasileiras, apesar da diversidade de suas manifestações, tem, na atualidade, destruído mais as possibilidades da vida urbana e aumentado a população submetida às práticas habitacionais perversas e, cada vez mais, degradantes. Mas se discutiu como é possível redirecionar esse tipo de urbanização, e foi considerado que a variedade de instrumentos urbanísticos que o Estatuto da Cidade disponibiliza torna viável propor uma urbanização mais digna e menos espoliativa. Considerações atuais sobre a desqualificação habitacional na cidade de São Paulo constituiu-se em um retrato das condições de vida que têm sido criadas por práticas predatórias e a rigor anti-urbanas de construção e uso da cidade brasileira.

Dentro da preocupação de tornar-se conhecido o Estatuto da Cidade foi distribuído o seu texto completo e as apresentações destacaram as possibilidades dos instrumentos urbanísticos, alguns já antigos, que esta nova lei reúne, propondo que a sua utilização deveria ser acompanhada de uma modernização da gestão urbana e de um processo democrático na construção da cidade que assegure sua efetividade social. É nessa perspectiva que se organiza a nova área de ensino e pesquisa em pós-gradução: Hábitat: Produção, Conflito e Políticas Públicas. Este foi mais um pequeno passo.

\section{Paulo César Xavier Pereira}

Professor do Departamento de História da Arquitetura e Estética do Projeto e orientador do curso de Pós-Graduação da FAUUSP. 